Article

\title{
Emergence of Carsharing Business Models and Sustainability Impacts in Swedish Cities
}

\author{
Nancy Bocken *, Alexandra Jonca, Karolina Södergren and Jenny Palm $\mathbb{D}$ \\ The International Institute for Industrial Environmental Economics (IIIEE), Lund University, P O Box 196, \\ SE-22100 Lund, Sweden; al0308jo-s@student.lu.se (A.J.); karolina.sodergren@iiiee.lu.se (K.S.); \\ jenny.palm@iiiee.lu.se (J.P.) \\ * Correspondence: nancy.bocken@iiiee.lu.se
}

Received: 13 December 2019; Accepted: 10 February 2020; Published: 20 February 2020

check for updates

\begin{abstract}
The sharing economy has become prominent in the policy, business and academic discourse as a way to achieve greater levels of resource efficiency in sustainability transitions. An example is carsharing, which is regarded as a potential lever for change in sustainable mobility transitions. In this article we, apply the "ecologies of business models" perspective to investigate how carsharing initiatives have coevolved in Sweden. We focus on the city context as a useful unit of analysis to investigate carsharing in four Swedish cities: Gothenburg, Malmö, Stockholm and Umeå. Through qualitative case research, we investigate the following: How did carsharing business models coevolve in the studied cities? It was found that early notions of carsharing date back to the 1970s, but the concept has changed significantly over time, particularly with the emergence of (Internet) technology-based platforms. The findings suggest that carsharing is complementary to existing private car usage in cities, rather than a replacement. Based on this, we suggest pathways for local policymakers to consider when implementing sustainable carsharing solutions. The contributions are threefold: providing an empirical study on the theoretical ecologies of business models concept; understanding how carsharing coevolved in Swedish cities and in relation to wider sustainability and mobility trends; and giving novel insight into the role of local governments.
\end{abstract}

Keywords: sharing cities; sharing economy; carsharing; sustainable business models; business model innovation; urban sustainability; ecosystems

\section{Introduction}

The sharing economy and related business models have become prominent in the sustainability discourse $[1,2]$. The central idea is to optimize the use of underutilized assets (e.g., cars and apartments) by pooling or sharing them through digital platforms [3,4]. Carsharing is increasingly studied as a phenomenon in the field of sustainability [5], the sharing economy [2,6,7], and the digital revolution [8] as digital platforms (e.g., Uber, Citymapper and Mobike) have the potential to disrupt current systems of provision in relation to urban development. Carsharing is regarded as a potential lever for change to reduce car dependency, congestion and pollution in cities and to contribute to broader socioeconomic issues such as health and access to mobility $[4,9]$. There are high expectations on sharing cities and sharing business models as ways to drive sustainable development [9-11].

Over time, various sharing business models have emerged in cities, but the actual impacts on society, the environment and the economy have been debated [2,11]. Simultaneously, there is great interest in smart cities and using digital platforms [12]. However, these developments are nascent and the full potential for sustainability and wider impact are little understood. The role of sharing business models and their impact in an urban context needs more research and critical investigation. This article 
will contribute to advancing the understanding of the development of carsharing business models in an urban context and the role played by local governments.

One way of exploring the emergence of sharing business models and the impact on incumbent business models and infrastructures is the 'ecologies of business models' concept, which analyzes the symbiotic and competitive relations between new and existing business models [2,13]. The concept builds on a metaphor of ecological dynamics in natural ecosystems (by [2], based on [14]) to advance understanding of how new business models influence existing ones through mechanisms such as competition, symbiosis and mutualism—processes also found in nature [2]. This would improve the understanding of the impact of new sharing initiatives in cities. For example, to what extent does a carsharing business model reduce dependency on cars or, instead, stimulate more car usage?

While business models have been analyzed in isolation (e.g., [15]), nascent research [2,5] suggests that business models need to be understood in their wider context, in particular in relation to other business models. This study seeks to extend work on ecologies of business models [2,13], which articulated the importance of analyzing the totality or patterns of business models in a context rather than single business models. This is done by investigating how carsharing initiatives coevolved over time in four Swedish cities. This research also seeks to extend earlier studies on carsharing in the German context $[5,9]$ and older studies on sustainable mobility and carsharing in Sweden $[10,16]$. This study will investigate the following research question: How did carsharing business models coevolve in the studied cities? A case study approach is taken by analyzing carsharing initiatives in Gothenburg, Malmö Stockholm and Umeå (Sweden), focusing on various carsharing business models as well as their relationships with each other and the cities. The next sections describe the background (Section 2), method (Section 3), case results (Section 4), and discussion and conclusions (Section 5) in greater detail.

\section{Background}

This section first discusses sharing business models and the ecologies perspective. Next, we zoom into carsharing as a specific type of sharing business model. We end with the research gap that forms the focus of this study.

\subsection{Sharing Business Models_-Opportunities and Challenges}

Business models describe the way business is done and are typically depicted by means of the value proposition (what is offered and to whom?); how that value is created and delivered (e.g., key activities, partnerships and channels); and how money and other forms of value, such as benefits to society, are captured [17-19]. Sustainable business models are regarded as a potential driver for sustainability [20], by taking a holistic perspective on the way business is done, and explicitly including society and the environment as stakeholders alongside the customer [21]. Sustainable business models are about "how an organization creates, delivers and captures value for its stakeholders in a way that supports a safe and just operating space for humanity and all living entities to flourish" ([22], p. 2).

The sharing economy is one possible example of a sustainable business model, which specifically recognizes the need to leverage the idling capacity of goods and services by offering access over ownership to reduce overall consumption and resource use [23]. This can manifest in many forms of sharing, such as sharing cars, homes or power tools [4].

Acquier et al. [4] proposed an organizing framework for the sharing economy that rests upon three pillars: (1) access economy (sharing underutilized assets to optimize resource use), (2) platform economy (digital platforms creating decentralized exchanges among peers) and (3) community-based economy (coordination through "non-contractual, non-hierarchical or non-monetized forms of interaction" (p. 6). The new elements in the sharing economy, compared to simply sharing items with family, friend and neighbors, is the concerted effort through a business model, involving financial transactions and the use of digital platforms to better use idle capacity [2].

Because of the ambition to leverage the idling capacity of goods and services through different modes of collaborative access, instead of traditional individual ownership, the sharing economy 
may lead to reduced resource use, requiring fewer physical goods [23,24]. However, concerns have been raised on the operationalization of the sharing economy $[25,26]$, in particular related to their actual impact. To illustrate, Kamargianni and Matyas [25] argued that it is rather easy to come up with new ideas but the real challenge is to put them into practice. Designing a business model and institutionalizing it is especially demanding when innovations occur outside the exclusive control of traditional firm boundaries (p. 3). Furthermore, despite the interest and promise about the sustainability impacts of sharing (and more generally, sustainable) business models, few studies have assessed their impact $[13,27,28]$.

Building on $[2,25,26]$, we suggest that it is difficult to understand the impact of one business model without knowing its broader context. Boons and Bocken [2] proposed an "ecologies of business models" approach to understand how sharing business models evolve compared to incumbent models and infrastructures: the shaping of individual business models takes place in an institutional setting which provides "rules" that are conducive to certain forms of product and service provision. Moreover, the shaping occurs in a context where other business models are present, which may compete, complement or provide vital inputs for the development of the sharing business model [13]. Taken together, this makes it advisable to analyze the "localized business ecosystem rather than an individual business model" alone ([13], p. 1501). Investigating the ecosystem through the ecologies of business models perspective is an important first step to assess carsharing's impacts on car ownership, emissions and sustainable transport in cities.

\subsection{Carsharing Business Models in an Urban Context}

Cities offer particularly fertile breeding grounds for sharing economy initiatives [29]. Davidson and Infranca [30] discussed how proximity and population density bring about agglomeration benefits. Today, $53 \%$ of the world population lives in cities-a number that is expected to grow to $66 \%$ by 2050 [31]. The potential for cities to leverage different resource-efficient sharing initiatives is therefore high and makes them a valuable unit of analysis as a geographically limited entity, with limited space for infrastructure, initiatives and services [32].

One area that is receiving a lot of attention is shared urban mobility [33]. The sustainability aspects of urban mobility business models relate to favoring clean energy; maximizing the use of transport resources and capabilities; encouraging substitution using sustainable alternatives; offering service orientation and functionality; articulating initiatives that address the needs of a wide range of stakeholders in transport systems; reducing travel demands; extending benefits to society and the environment in a systemic perspective; and developing scale-up mobility solutions [33].

Studies have shown that car-based personal mobility is lessening its share of urban travels in the developed world [34] and, simultaneously, that new mobility services are entering the market. Carsharing is an example of a mobility solution that is gaining ground in cities worldwide [35]. It offers temporary access to locally available cars [9] and has the potential to reduce the number of cars on the road [26] but could also increase car dependency [2]. As suggested in [36], functionality is delivered rather than ownership in carsharing business models. A different kind of value proposition is therefore put forward, alongside strategies for value creation and capture [5].

In their research on sustainable business models, Schaltegger et al. [5] identified coevolving processes of business model variation, selection and retention in a German context. Most notably, they explained an evolution from station-based models where cars are picked up and dropped off at specific carsharing stations (e.g., Greenwheels) to more free-floating setups that allow cars to be picked up and dropped off at any place in a defined urban area (e.g., Car2Go and DriveNow). Similarly, Münzel et al. [9] analyzed and compared carsharing business models in Germany and distinguished between cooperative, business-to-consumer and peer-to-peer (P2P) carsharing models. Recognizing that different carsharing companies (and hence, business models) have different fleet sizes, they argue that they are still "equally competitive in terms of the number of cars they offer per capita in the geographical area they operate in" ([9], p. 272). Similar to [2], they conclude that various carsharing 
business models can and will coexist "for a rather long time in their respective areas of operation" and that relational interdependencies, therefore, are inevitable [9], p. 272.

These interdependencies observed in literature suggest that shared urban mobility and "mobility as a service" (MaaS) have organically emerged as concepts [37], drawing from experiences in Finland, the Netherlands and the United Kingdom [38]. MaaS "aims to bridge the gap between public and private transport operators on a city, intercity and national level" [25], p. 3, by integrating different tools (e.g., planning, booking, payment and ticketing) and services (public transport, carsharing, bike sharing, taxi, etc.) into one seamless travel platform [39,40]. MaaS thus has the potential to integrate a whole ecosystem of business models. However, scholars have argued that it will take time before substantial levels of needed cocreation are reached [41]. We need not only a better view on the roles and relationships of different actors involved [25] but also a better understanding of their respective business models as well as the willingness and ability to share data when cities seek to establish an integrated mobility service offering. More research is also needed on the role of the city that is offering geographical space for carsharing to function and the policies and regulations that affect the evolution of carsharing business models [31,40]. MaaS will not be the focus of this article; however, it is touched upon when mapping how carsharing evolved in the four Swedish cities.

\subsection{Research Gap}

This research seeks to bridge research gaps in the fields of sharing business models and urban sustainability transitions by understanding how carsharing coevolved in four Swedish cities.

Literature provides understanding of what "sharing" is [4,23], but little work has been done on how individual initiatives can scale up to form a viable economic system to live up to positive environmental, social and economic expectations (an exception is [42] as argued in [2]). There is a clear need for a better understanding of how sharing initiatives evolved in cities to learn from this for the future. Furthermore, earlier work conceptualized how business models might coevolve [2,13], but empirical data is lacking. The broader gap in business model research relates to understanding their impact. The move away from a dominant "unsustainable" business model is still an open area for research [43].

Although the literature has increasingly pointed towards the role of business models in sustainable urban mobility, less focus has been on understanding the size of new industries such as carsharing and the dynamics of these new business models in an urban context. There is a considerable amount of knowledge at the firm level, but little is known about how those business models can be feasibly diffused in cities by both public and private actors $[5,33]$.

While authors have studied carsharing in contexts like Germany [5,9], the focus was on exposing the emerging landscape rather than the roles of local governments. The role of local governments is also underexplored in the development of sharing business models (with exceptions, e.g., [10]), whereas the urban context has been identified as a promising unit of analysis. The importance of local governments has been highlighted before but in relation to local markets for electrical vehicles where public procurement was identified as a key policy means [44]. Through qualitative case analysis, we analyze the coevolution of carsharing over time and the role of local governments as potential "orchestrators" of carsharing in cities, in this way bridging sharing business models and urban governance research.

\section{Methods}

The data collection was part of the Sharing Business Models project, a strategic research project on novel business models for the sharing economy in cities. The project aimed to better understand the impact of sharing business models by investigating the emergence of such new business models in a city context and is part of the wider national program called "Sharing Cities Sweden" (www.sharingcities.se), which aims to "develop world-leading testbeds for the sharing economy in Stockholm, Gothenburg, Malmö and Umeå". 
We focus on cases of four cities in Sweden (Umeå, Gothenburg, Stockholm and Malmö; Table 1) to analyze the development of carsharing in the context of other mobility developments. Data collection included document and archival analysis, a focused workshop with cities' representatives, and 7 semi-structured interviews with city representatives and experts related to carsharing in the cities to comment on the developments in the cities (see Figure 1). Data collection took place between February 2019 and December 2019.

Table 1. Detail of the four cities being investigated. Sources: References [45-47].

\begin{tabular}{ccc}
\hline Cities & Size (Inhabitants) & Information \\
\hline Gothenburg & 573,852 & $\begin{array}{r}\text { Site of the Port of Gothenburg-the largest in the Nordic } \\
\text { countries: Testbed city of Sharing cities Sweden. } \\
\text { One of the early industrialized towns in Scandinavia: Testbed } \\
\text { city of Sharing cities Sweden. }\end{array}$ \\
Stockholm & 340,802 & $\begin{array}{r}\text { Capital city of Sweden and most populous in Sweden and across } \\
\text { the Nordic countries: Testbed city of Sharing cities Sweden. } \\
\text { City located in the middle/northeast of Sweden: Testbed city of } \\
\text { Sharing cities Sweden. }\end{array}$ \\
\hline
\end{tabular}
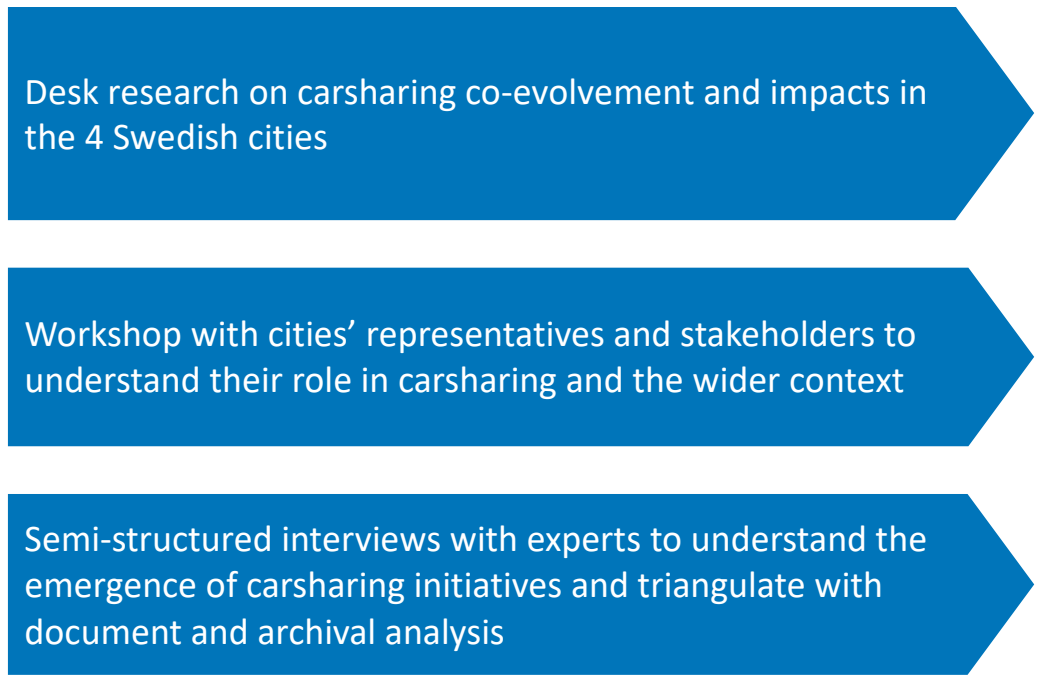

Figure 1. Method applied in this research.

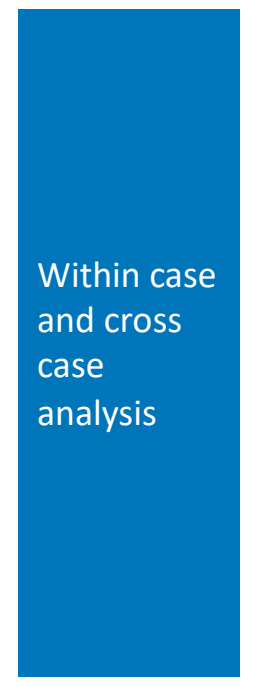

The focus is on four cities and the different business models operating therein. An ecologies of business models perspective [2] was adopted by analyzing the coevolving business models in a city context.

\subsection{Desk Research on Carsharing Organizations}

Websites of carsharing organizations operating in the four case cities were analyzed for their business model characteristics. Documents such as books, articles and reports about carsharing in Sweden were also examined to track the evolution of carsharing over time, including when specific organizations started operating in the case cities. In some cases, emails were sent to organization representatives if data could not be found on websites or in documents. As a comprehensive website or database of all carsharing organizations in Sweden is yet lacking, this iterative approach was used to uncover prominent carsharing examples in the different cities, coupled with the insight from the workshops (Section 3.2) and expert interviews (Section 3.3). 


\subsection{Detail about the Workshop}

A 2-h workshop was held on 8 April 2019 at Lund University, with city representatives and stakeholders. This workshop took place as part of the Sharing Cities Sweden program and focused on learning about (car)sharing business models. Over 80 representatives from academia, municipalities and business attended the Sharing Cities event, and 22 invited experts attended the more focused afternoon workshop. The group of 22 participants included eight representatives from Lund (five academic and three city representatives), three representatives from Malmö (all city representatives), five representatives from Gothenburg (all city representatives), three representatives from Stockholm (academic representatives working on sharing projects with the city) and three representatives from Umeå (all city representatives). During this workshop, participants were asked about the governing role and responsibilities they see the city taking with sharing, how the ecologies of business models framework applies to mobility in the respective cities, and how digitalization and data more generally can be used to accelerate the sharing economy.

\subsection{Interviews}

Semi-structured interviews were conducted with city actors working with carsharing from each of the four cases. Seven interviews were conducted between October and December 2019. This included one interview with a representative from Malmö, two interviews with representatives from Gothenburg, one interview with a representative from Stockholm and one interview with a representative from Umeå. In addition, two experts not associated with a specific city were consulted to better understand the wider carsharing context (see Table 2). Existing contacts in each of the four cities were asked for introductions to representatives that were working with carsharing; interviewees were also selected on the basis of having worked with carsharing or sustainable mobility in their respective cities for at least one year. The knowledge gained in the interviews differed from available public data as individuals could reflect on the barriers to carsharing, carsharing's role within sustainable mobility efforts and expectations placed on carsharing. Interviews took between $30 \mathrm{~min}$ to one hour.

Table 2. Detail about the interviewees.

\begin{tabular}{cccc}
\hline$\#$ & Interviewees & Representative/Expert for City of & Type of Interview \\
\hline 1 & Project Leader & Gothenburg & Phone \\
2 & Project Manager & Umeå & Zoom \\
3 & Cooperative Representative & All & Skype \\
4 & Traffic Planner $(\times 2)$ & Gothenburg & Zoom \\
5 & Carshare company representative & All & Phone \\
6 & Traffic Planner & Malmö & Zoom \\
7 & Project Manager & Stockholm & Zoom \\
\hline
\end{tabular}

The interviews were used to validate the results of the document and archival analysis and workshops. Interviewees were asked about the role carsharing plays in their city's sustainability efforts, how carsharing business models evolved over time and how the city's institutional framework interacts with carsharing organizations. This was done to ensure a complete understanding of how the ecologies concept applies to carsharing in the Swedish case cities and to develop comprehensive narratives about the evolvement of carsharing.

\subsection{Data Analysis}

Information from the three data sources was coded manually according to the three case study components: carsharing business model evolvement in the city, governance and impact. The interviews were recorded with explicit permission and listened to several times to ensure no important information was overlooked. Follow-up emails were sent for clarifying questions and additional data. 


\subsection{Limitations}

First, as there is not one official or up-to-date website or database where carsharing organizations are tracked, it was challenging to confirm with certainty when a specific business model started operating in a city as well as the total number of organizations operating in a given city. Information about nonprofit cooperatives is available (http://www.bilcoop.se/), but not for Business-to-Consumer (B2C) and Peer-to-Peer (P2P) providers. Even our enquiries and communications with the respective companies and city representatives could not always lead to exact timelines. Instead, the timelines provide a best estimate for operations and serve to highlight how the models have evolved over time in the case cities. Second, it appears from our efforts to identify carsharing and mobility experts in cities using the Sharing Cities project network that carsharing is still quite niche, and few experts could be identified. This led to a limited number of interviews. Third, we took carsharing as the starting point and focus of study. Hence, we did not look into the full detail of new business model developments related to bikes, scooters, public transit and their business model evolvement. These are out of the scope of this present study, yet we do focus on the broader trends related to mobility in the cities to assess the impact of carsharing.

\section{Results}

The results start with the context of carsharing in Sweden, followed by outcomes for the specific cities and a brief cross-case analysis.

\subsection{Context and Evolution of Carsharing in Sweden}

This section provides a brief context and description of the evolution of carsharing in Sweden. Table 3 provides a brief typology of carsharing in Sweden, presenting the different types and examples identified in Swedish cities. These were identified based on the desk research. Figure 2 shows how carsharing developed over time in the Swedish context.

Table 3. Typology of carsharing in Sweden.

\begin{tabular}{cccc}
\hline & Cooperative Model & Business-to-Consumer (B2C) & Peer-to-Peer (P2P) \\
\hline Fixed spot & Bilpoolen, Sambil & Sunfleet, MoveAbout & Snappcar, GoMore \\
\hline Free floating & & Aimo & \\
\hline
\end{tabular}

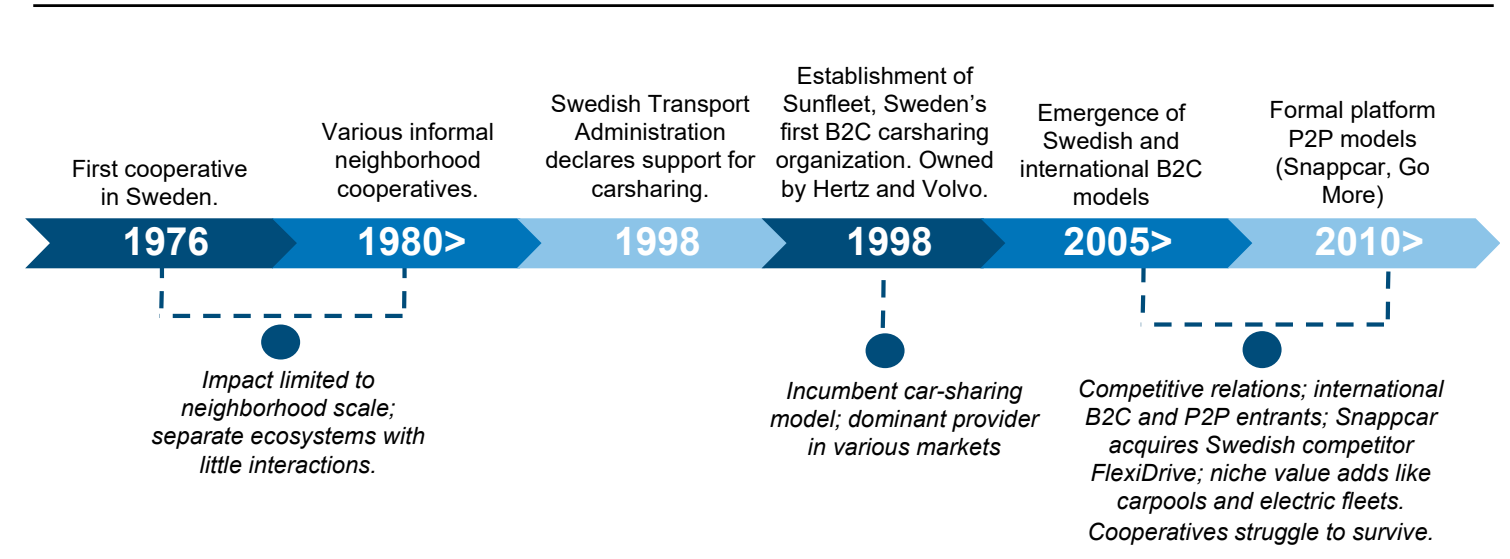

Figure 2. How carsharing developed over time in Sweden (developed in this research).

Carsharing in Sweden began in the 1970s with nonprofit peer-to-peer cooperatives where neighbors would pool together resources to own cars collectively or participate in carsharing organizations [48]. After the Swedish National Road Administration (SNRA or Vägverket) had been assigned to take care of sustainable transport, their strategies would include carsharing and carpooling as important components to developing sustainable transport in Sweden [48]. 
With national government support, carsharing models began to proliferate from the late 1990s onwards. This was further facilitated by the use of technology as users could easily book cars through apps at their convenience. Carsharing membership doubled approximately every two years, and more competition between carsharing businesses emerged [49]. Nevertheless, legislation at the national level has been slow to accommodate different business models.

Three main business models have emerged within the Swedish context: cooperative models, Business-to-Consumer (B2C) models and Peer-to-Peer (P2P) models.

\subsubsection{Cooperative Models}

In the case of cooperative models, vehicles are either owned by a member and shared with the cooperative, or members pool together finances to maintain joint ownership of a vehicle. Members pay a membership deposit, yearly or monthly fees and for mileage. The maintenance and care of the vehicles is often contractually obliged, including bookkeeping and administrative duties. In turn, members can book cars with parking costs, insurance and fuel included in the price for rental periods. Cooperatives generally follow roundtrip models where vehicles are returned to where they are picked up. Early carsharing models were often driven by cost-savings as a value proposition rather than environmental concerns [50].

The first carsharing cooperative in Sweden, Bilpoolen, operated from 1976 to 1979 [48]. Sambil is the oldest active example of such an organization and is currently present in several Swedish cities, including Stockholm and Gothenburg [48,51]. While users retain ownership of their vehicles, these organizations maintain contact information and ease the process of car lending to members that do not own vehicles [50]. This model inspired the development of carsharing over the next two decades in Sweden [50].

While these carpools were limited to select geographical areas and several dozen members were given limited available vehicles, the organizations were given early stage funding from the Swedish national government to monitor their success and to track impact over time [48]. Despite facing no significant competition at this time, the size of these early-stage initiatives limited the environmental impact to the neighborhood scale and ultimately did not result in a systemic transportation shift as car ownership continued to increase by an average of $1.4 \%$ from 1980 onwards [52]. Small, neighborhood-scale cooperatives can still be found throughout Sweden.

\subsubsection{Business-to-Consumer (B2C) Models}

The late 1990s and early 2000s saw B2C models emerge that diversified from the traditional cooperative model. B2C models are characterized by a for-profit third-party providing a fleet of vehicles [9]. While some cooperative models involve a third-party, facilitating transactions (as opposed to members handling administrative duties), cooperative models involve joint ownership of the vehicles to some extent. Thus, B2C models differ from cooperatives within the ownership component.

Under B2C models, members select a membership type (hourly, daily, monthly, etc.) according to their expected usage for which they will make a one-time or monthly payment. Fuel costs and congestion charges are usually included in the per $\mathrm{km}$, hourly or weekend fees. There are variations in B2C business models regarding membership types, offering roundtrip vs. one way, and establishment of business-to-business (B2B) carpools as part of the offering.

Carsharing in the 2000s was thus either highly localized with cooperative models or driven by car rental companies like Sunfleet. In 2009, carsharing was available in 37 cities, but only two providers operated in more than one location; only 7 out of 45 providers had "more than 100 customers or more than 10 vehicles available" while Gothenburg and Stockholm had 9 and 10 providers during this time, respectively [53]. Business has traditionally been the largest carsharing market segment in Sweden, attracted by the proposition of temporary rentals for business trips, followed by planned communities (i.e., new developments) and residential neighborhoods [50]. 


\subsubsection{Peer-to-Peer (P2P) Models}

Under P2P models, vehicles are lent from user to user through an online platform, generally for profit. Users can select from the vehicles available in their area. The duration of the car share is generally up to the vehicle owner's discretion as they set the terms. Often, these models include a rating function on the website for both the lender and the borrower. P2P models are not tied to a location as they are dependent on users in an area advertising their vehicles.

The P2P carsharing Dutch company Snappcar entered the Swedish market in 2012. Users can advertise their car on the platform wherever they are located and charge a daily fee for use. Owners of the vehicles retain ownership and handle maintenance compared to carsharing cooperatives. Snappcar acquired Swedish competitor FlexiDrive in 2015 [54]. This acquisition was initially met with outrage despite the business model remaining the same with only a name change; user trust had to be developed by Snappcar again (Interview 5). Snappcar is present in cities across Sweden though the unstable vehicle fleet within P2P organizations inhibits formalized partnerships, meaning P2P organizations have to rely on more casual users (Interview 5).

GoMore is a Danish P2P carshare company that started operating in Sweden in 2015, with vehicle leasing and P2P ridesharing for profit also offered as a value add. Users can lease new vehicles through the company and either pay a set monthly fee for or a discounted monthly fee if they rent the car to other users for a certain amount of days each month. The P2P function is now discontinued, but it allowed users to advertise their destination with a proposed price for splitting the trip costs [55]. For-profit ridesharing has faced regulatory difficulties in Sweden; while it can be a value add for carsharing organizations, the national government is still weary of an unregulated P2P ride-hailing or sharing market and has strict regulations in place that prevent ridesharing from taking over taxi services [56]. Thus, within an ecology of mobility models, ridesharing does not pose the same competition to carsharing that may occur in other cities.

\subsection{Specific Developments in the Four Swedish Cities}

This section will explain the evolution of carsharing in the four cities in light of the evolution of other modes of transport and impacts.

\subsubsection{Carsharing in Gothenburg}

Figure 3 summarizes the evolution of carsharing in Gothenburg. The carsharing business model trajectory in Gothenburg began with cooperatives, followed by an expansion of B2C and P2P models. Göteborg's bilkooperativ in Gothenburg was inspired by early cooperatives, forming in the 1980s. The company struggled to afford their vehicles and merged with another cooperative in 1990 [48]. The new organization was named Majornas Bilkooperativ, which became Sweden's largest nonprofit carsharing cooperative with 20 cars and 200 users [48]. Majornas Bilcooperativ shut down in 2018 due to declining membership numbers and difficulties in getting members to engage in mandatory cooperative activities [57] (Interview 3). One interviewee suggested that membership and maintenance duties are no longer something people want to participate in and that cooperatives need to adapt accordingly (Interview 2). While there are still active cooperatives in Gothenburg, such as Masthugget's Car Cooperative and Bagarbil, they face increasing competition from commercial operators such as Sunfleet, who can offer low rates without the volunteer requirements [57]. 


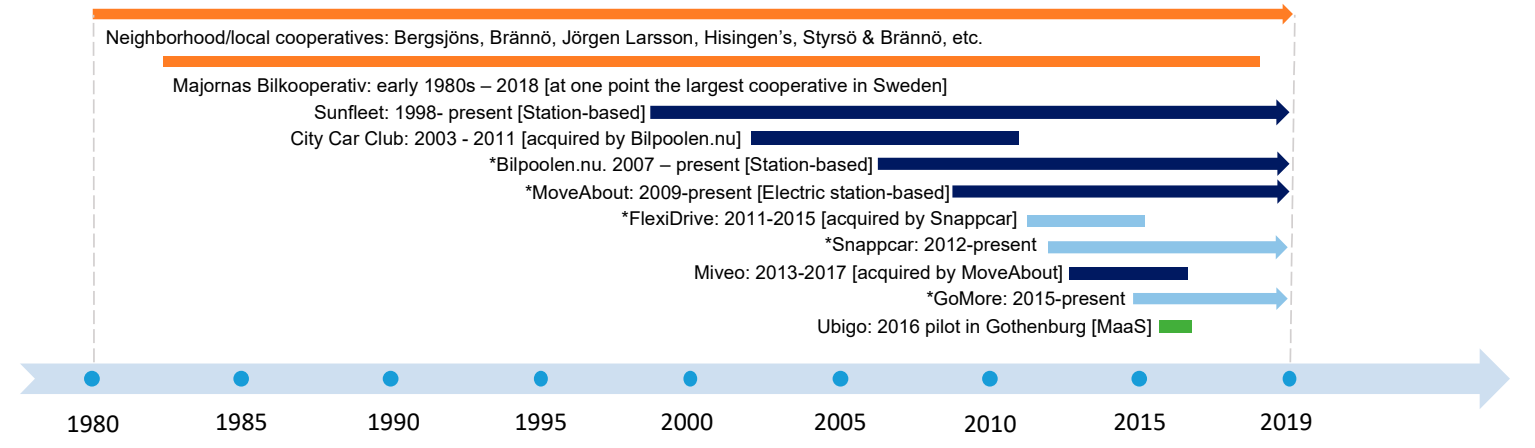

Figure 3. Gothenburg carsharing evolution. Orange: cooperatives; dark blue: B2C carsharing; light blue: P2P; green: mobility as a service (MaaS); some offer additional value creation, e.g., B2B carpools.

* Refers to an estimate-exact operational starting date in Gothenburg could not be confirmed.

The establishment of Sunfleet in Gothenburg in 1998, after the announcement of the Swedish government's support for carsharing, marked a critical turning point in Swedish carsharing as it would become Sweden's largest carsharing organization. Sunfleet operates a commercial B2C station-based model where users book vehicles to pick up and drop off at specific locations. Sunfleet's value proposition differed from cooperatives in several ways: operating in more locations; providing users flexibility in vehicle choice and differing rental times and membership types; and not requiring volunteer duties. Sunfleet is the predominant carsharing organization in Gothenburg today with more than 180 private and open pick-up/drop-off locations around Gothenburg [58], though Bilpoolen.nu and MoveAbout also have a B2C presence (Interview 4).

Technology largely permitted the scalability of different models that could offer multiple services, as users could use websites and apps to search for and book vehicles, making the process highly convenient. Organizations like Bilpoolen.nu, created in 2007 in Gothenburg, establish carpools for businesses or apartments and offer P2P rentals [59]. Bilpoolen.nu was successful enough to eventually take over City Car Club, an international competitor [60]. MoveAbout maintains a similar business model with a niche value add; setting up electric carpools for companies and organizations as well as offering cars for round trips to private individuals for a membership fee and rental costs [61]. MoveAbout took over another Swedish electric car company, Miveo, in 2017 [62]. MoveAbout attracts a smaller subset of the population and can capture value by upholding their business model as a way for customers to become 'truly sustainable travelers' [61]. Large operators like Sunfleet now also offer carpools for private businesses and organizations, creating competitive relations with other business models. However, smaller B2C or P2P operators pose little threat to Sunfleet given its incumbent backing and market dominance [2].

Gothenburg was also the first city in Sweden to experiment with MaaS. UbiGo was an app that was piloted in Gothenburg in 2015 and allowed users to enter their journey destination and to choose from a variety of transport methods (bikes, cars, etc.). While the UbiGo app saw success, it was discontinued at the time as there was no one willing to take ownership of the app's management (Interview 4). Sunfleet was the carsharing partner, again demonstrating the company's predominance and capacity to provide for large customer base.

\section{Governance of Carsharing}

The city of Gothenburg started to take an active role in promoting carsharing in the early 2000s when the Gothenburg Urban Transport Administration developed a proposal to encourage the use of carsharing by residents and the city [63]. The city procured Sunfleet services to act as a first mover in the space, to strengthen the market and to help carsharing achieve critical mass (Interview 4). Without early city support, one interviewee viewed the business model as unlikely to have succeeded (Interview 4). Thus, the city had an early role as an enabler, providing the required infrastructure and support for carsharing to succeed on a larger scale than neighborhood cooperatives. 
The city provides a conducive environment for carsharing through favorable parking conditions and procurement. Gothenburg now has an internal carsharing scheme and leases cars through the B2C company bilpoolen.nu (Interview 1). Gothenburg's 2009 Parking Policy encouraged the use of carsharing by lowering the number of parking spaces required for developments; developers have a $10 \%$ reduction in required parking spaces if there is proximity to public transit [64]. The 2014 Traffic Strategy included an objective to increase the number of parking spaces for carsharing schemes by public squares, key transport nodes, and other areas of high interest and activity [65]. The number of parking spaces in the city for shared vehicles has increased significantly, from 81 in January of 2017 to 218 in December of 2019 (Interview 1). Providing adequate infrastructure is an important impartial mechanism for cities to promote carsharing.

Trends in the Urban Mobility Context

Private car trips overall have decreased since 2009, which is correlated with the introduction of a congestion tax and a rise in bicycle trips and public transport in the city's datasets rather than carsharing [66]. Air pollution from Particulate Matter 10 has halved in the last decade, and volatile organic compounds (VOCs) have gone down as well [67]. Both are pollutants commonly associated with car exhaust, but the change is also attributed to the congestion tax and the rise in bicycle trips and public transport [66]. Total personal vehicles in use went up from 175,247 in 2010 to 189,509 in 2018 [67]. This represents growth of $8.13 \%$ from the 2010 baseline. While the share of electric and hybrid vehicles has been increasing (electric went from almost zero percent of new vehicle registrations in 2010 to $2 \%$ in 2019) and diesel vehicle registration has gone down, the share of petrol vehicles in new registrations has remained steady [67]. Whereas people appear to use their cars less and electric vehicle ownership is growing, car registration is increasing despite other mobility options.

While most cities want to look at decreased car usage as a measure of sustainability impact, it can be difficult to attribute reductions in car usage to carsharing given promotion of public transportation and biking (Interview 4). During the workshop, mobility was not brought up as something prioritized by the city within its governing of the sharing economy [Workshop]. The city's role was referred to as a supporter and enabler, which Gothenburg's procurement partnerships have demonstrated [Workshop]. The Gothenburg Urban Transport Administration struggled in the past to change street parking ordinances to allow for more carshare services [63]. The municipality itself was the largest carshare user for a decade, with 4600 municipal employees using cars provided by Sunfleet in 2012 compared to 717 public members [63]. This has changed: while membership in cooperatives remained steady from 2012-2017, both MoveAbout and Sunfleet have experienced growth. In Gothenburg, MoveAbout had 6448 total users in 2016 while Sunfleet had 10,886 (Interview 4). MoveAbout is thus able to compete with Sunfleet in Gothenburg (Interview 4). Gothenburg is also Snappcar's second largest market (Interview 5). While there are still significantly more private car owners in Gothenburg, B2C carsharing organizations are growing.

\subsubsection{Carsharing in Stockholm}

As the largest city in Sweden, Stockholm has seen a variety of business model experiments. Sunfleet did not start operating in Stockholm until 2008 and, as of 2019, has about 20 private and open carpool locations advertised on their website, significantly lower than the 180+ in Gothenburg despite Stockholm's larger population [68]. Other B2C models offer carpools, rideshare services and niche vehicles (i.e., electric). Stockholm is Snappcar's largest market "by far", indicating a possible preference by residents for P2P sharing (Interview 5).

Free-floating services have failed to make an impact in Stockholm despite offering a flexible and immediate value proposition. Free-floating, or one way, B2C organizations allows users to pick up and drop off cars at permitted locations in the city. Membership and distance fees generally follow the same model as roundtrip companies. While roundtrip models could be imagined to act mutualistically with free-floating services as they serve two needs, free-floating services' entries into the ecosystem has 
been squashed in a parasitic manner by existing organizations alongside lacking public demand and supportive parking infrastructure [69]. Car2Go, which started operating in Stockholm in 2014, ceased operations in 2016 as did DriveNow in 2018 [70]. A consultancy report from Rise Viktoria found that Car2Go usage rates in Sweden were extremely low in Stockholm compared to other European cities, likely contributing to Car2Go's shutdown in addition to strict regulations about where cars could be parked [70]. Public transportation and bicycling remain highly viable options in Sweden, possibly contributing to the lack of public free-floating uptake and the smaller carsharing user base. Currently, only Aimo — an electric one-way service (free floating)—is available in Stockholm, though it has only been active for a year as of 2019 [71].

Round trip models are generally used for longer trips given the lack of flexibility for pick-up and drop-off locations and need to plan ahead. Free-floating services like Aimo compete directly with public transportation and bikes given they are meant to be used for short trips within the city. Efficient and affordable public transportation must be seen as a necessary complement to existing carsharing schemes as it cannot be the only alternative given the relatively high marginal cost of participating in carsharing compared to using one's private vehicle [49]. Public transportation and carsharing thus act in a mutualistic fashion to reinforce the ultimate goal: significantly reducing private car ownership $[57,72]$. Figure 4 summarizes the evolution of carsharing in Stockholm.

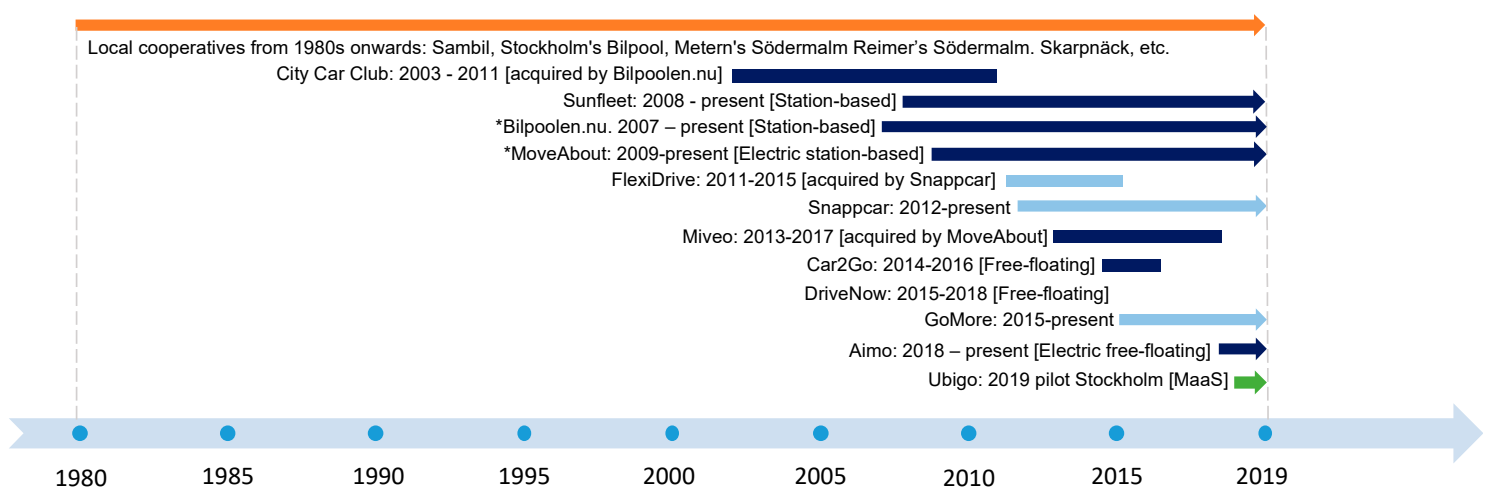

Figure 4. Stockholm carsharing evolution. Orange: cooperatives; dark blue: B2C carsharing; light blue: P2P; green: MaaS; some offer additional services, e.g., B2B carpools. * Refers to an estimate-exact operational starting date in Stockholm could not be confirmed.

Governance of Carsharing

Stockholm began interacting with carsharing organizations in the early 2000s. As a participant in an EU funded project MOSES from 2001-2005, carsharing was promoted in municipal departments [73]. Several departments started using carsharing, and the project helped to further encourage the promotion of carsharing in Stockholm. Stockholm also has a vested interest in promoting electric vehicles and has participated in a join procurement scheme since 2010 to increase electric vehicle (EV) and plug-in hybrid electric vehicle (PHEV) viability [74]. This supports the dominant model of owning a vehicle within the existing mobility ecosystem rather than a system of car provision.

The city is attempting to move away from leasing through entering a procurement partnership with Sunfleet in 2018 (Interview 7). Out of the four companies that were viable options for the partnership, Sunfleet was able to secure the contract because of offering the lowest costs (Interview 7). The cars are available to the public when not in use by the municipal employees. To reduce dependence on car ownership, new developments can include fewer parking spaces than legally required if convenient sustainable mobility solutions are offered. A mobility index is being trialed where developers are scored according to residents' proximity and access to carsharing schemes, whether fewer parking lots are being built and if there are high parking fees [75].

However, carsharing does not appear to factor into the city's climate goals significantly; neither the 2010-2020 Climate Action Plan nor the Urban Mobility Plan mention carsharing [76,77]. While the 
city supports reducing available parking spots in the city center, carsharing has not played a significant role in sharing initiatives [Workshop]. This is largely due to regulations that do not allow Stockholm to favor private companies, making procurement their only current mechanism for explicit engagement (Interview 7). Public transportation, cycling and walking are also viewed as options that should be promoted and prioritized over carsharing (Interview 7).

While UbiGo was discontinued in Gothenburg, it is currently being trialed in Stockholm in collaboration with the public transport body SL [78]. Similar to the parking space mobility index, if developers offer subscriptions to UbiGo to their residents, the requirement to build the minimum number of parking spots is waived and buildings costs are thus reduced, providing a direct incentive for carsharing. UbiGo was required to enter a B2B partnership with Sunfleet to guarantee customers for Sunfleet as Volvo would not otherwise permit them to work with the app, fearing low customer use [79]. However, because of Sunfleet's dominance in Stockholm, there are probably no other operators who can provide the scale of vehicles needed for the app to succeed. Snappcar is an additional partner providing P2P services (Interview 5).

\section{Trends in the Urban Mobility Context}

The city has only formally surveyed transportation habits once in 2015. The study found that $1 \%$ of respondents participated in a carpool in Stockholm County in 2015 [80]. A separate survey looking at the city of Stockholm specifically found that $2 \%$ of residents used a carpool in 2016, a jump from $1 \%$ in 2010 [81]. However, total personal vehicles in use went up from 303,930 in 2010 to 355,457 in 2018 [67]. This represents a growth of $16.9 \%$ from the 2010 baseline-almost double the Gothenburg rate. While electric vehicles now make up $1.7 \%$ of the total new registrations (from $0.01 \%$ in 2010 ), petrol and diesel vehicles still make up $82 \%$ of new registrations. Even though electric and hybrid vehicles are on the rise and these numbers do not account for population growth, this still demonstrates a strong preference towards owning vehicles, despite the rise of trips made by public transportation, walking and cycling.

In addition to the lack of a national definition and the regulations preventing favoritism for private companies, Stockholm has been slower to engage with carsharing than other Swedish cities because of the perceived lack of conclusive evidence for the sustainability merits of carsharing (Interview 7). Free-floating services in particular can pose a threat to public transportation and cycling, and Stockholm wants to ensure that the travel methods it promotes are sustainable. Stockholm also views EU projects as avenues for experimentation with different carsharing modes, such as in the UbiGo pilot (Interview 7). Ultimately, the city does have a role to play as a mediator and facilitator that interprets regulations and communicates sustainable travel options to residents (Interview 7).

\subsubsection{Malmö Carsharing}

Figure 5 summarizes the evolution of carsharing in Malmö. Carsharing took off in Malmö in 2007 with CIVITAS SMILE, an EU program which provided funding to select cities to help them develop more sustainable urban transport systems [82]. As one of only two commercial operators in Sweden at the time, Volvo and its subsidiary Sunfleet were selected to establish five carsharing spots within Malmö between 2005 and 2007 [83]. Today, like in the rest of Sweden, Sunfleet is the largest carsharing vehicle provider in Malmö and has established more than 100 public and private parking spots [84]. The early government support helped cement Sunfleet's incumbent status. P2P carsharing emerged similarly as in other cities; platforms like Snappcar and GoMore became a usable model once users started interacting with and using the platforms.

As Malmö is a smaller city than Gothenburg and Stockholm, Sunfleet's dominance has resulted in few competitive relations between business models. The city is lacking the critical mass to create effective competition with other carsharing organizations, allowing Sunfleet to maintain its incumbent status. 


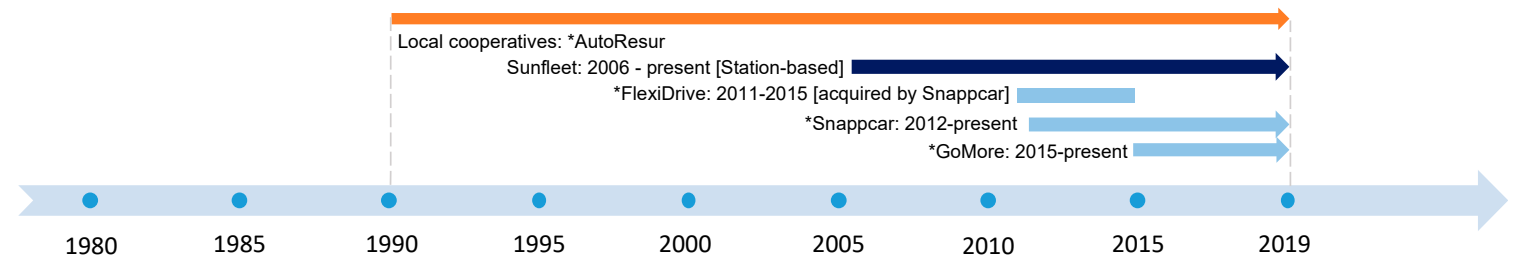

Figure 5. Malmö carsharing evolution. Orange: cooperatives; dark blue: B2C carsharing; light blue: P2P; some offer additional value services, e.g., B2B carpools. * Refers to an estimate-exact operational starting date in Malmö could not be confirmed.

\section{Governance of Carsharing}

The city does not procure carsharing services, citing laws that do not allow them to show favoritism for private companies (Interview 6). Instead, Malmö has promoted carsharing through providing information about carsharing and a parking norm that allows developers to reduce the required number of spots for inhabitants if they provide convenient access to sustainable mobility solutions (Interview 6). In a Malmö Västra Hamnan (West Harbor) project that attempted to incentivize new residents in a neighborhood to forgo travelling by car, a trial Sunfleet membership was offered [85]. While studies have identified regulatory tools at Malmö's disposal to promote carsharing-parking allowances, gradient parking fees for carshare vehicles and city zoning by laws that dictate where vehicles are able to travel and park - the city has not pursued these [49]. Some of these tools, such as reducing parking spots, would likely face political difficulties [49]. Nevertheless, organizations like Sunfleet and MoveAbout view lenient parking permits as one of the most important tools for increasing customers as parking costs continue to rise [49]. The city is also conducting a feasibility study into free-floating carsharing services to determine whether they can contribute to sustainability without disincentivizing public transport and cycling (Interview 6).

Malmö's comprehensive city plan promotes high densification with the vision that citizens can select public transport and biking over using a car [86]. The city's Sustainable Urban Mobility Plan also highlights that carsharing has increased in Malmö in recent years and that the city should continue to expand access to green vehicles via dialogue with constructors and developers [87]. The city's role has been expressed as an enabler leading the way (changing its own organizational processes to influence the evolution of sharing); though without procurement capabilities, it is difficult to do so for carsharing. Carsharing has not been a part of the city's sharing ambitions, which instead focuses on renting out property and goods [Workshop]. The city did initiate the "no ridiculous car journeys" campaign which has been replicated in other Swedish cities and encourages citizens to choose transportation methods other than private vehicles.

\section{Trends in the Urban Mobility Context}

Overall, car journeys have been declining in Malmö while public transit and biking have gone up, reflecting sustainable mobility trends [88]. Private vehicles in use went down to 106,869 in 2011 from 117,991 in 2010 (2010 being the most recent data available) but have been steadily increasing since then to reach 119,225 in 2018 in Malmö [67]. Of the new registrations, electric vehicles have gone from almost 0 in 2010 to make up $1.6 \%$ of newly registered vehicles; petrol and diesel vehicles now make up $91 \%$ as opposed to $84 \%$ in 2010, likely because hybrid vehicle registrations have overall decreased [67]. Thus, while it is clear that other sustainable modes of transport are being used, private vehicle use is still on the rise and nonelectric cars dominate in Malmö.

\subsubsection{Umeå Carsharing Evolution}

Figure 6 summarizes the evolution of carsharing in Umeå. Umeå has seen little business model evolution, likely due to its small size. Umeå has 27 shared cars available through Sunfleet and two cooperatives for its 88,000 residents in the urban center (Interview 2). Sunfleet started operating in 
Umeå in 2008, while Björkstadens Miljöbilpool was formed in 2009 as a cooperative where members share responsibility for vehicle maintenance; three vehicles are available through a booking system and located in one area of the city [89]. Ålidhems Bilpool is another organization with one car available in Umeå-members pay monthly, booking and mileage fees, and cleaning/administrative duties are shared [90].

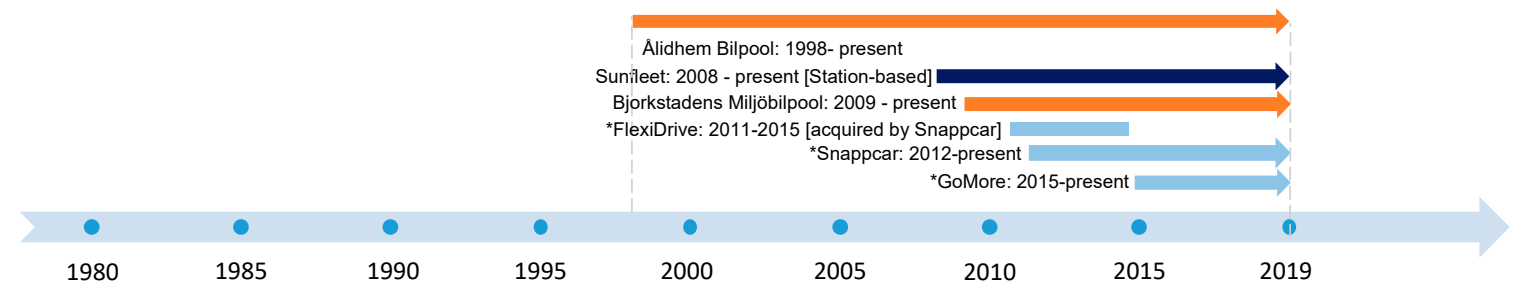

Figure 6. Umeå carsharing evolution. Orange: cooperatives; dark blue: B2C carsharing; light blue: P2P; some offer additional services, e.g., B2B carpools. * Refers to an estimate-exact operational starting date in Umeå could not be confirmed.

Governance of Carsharing

The municipality played a big role in bringing commercial carsharing to the town. Umeå entered an official procurement partnership with Sunfleet in 2008 to create a carpool available to municipal employees (Interview 2). Town residents are permitted to book vehicles when they are not in use by municipal employees, provided they have Sunfleet membership (Interview 2). Sunfleet did not have a presence in the town beforehand and engages in little advertising or promotional campaigns to engage more residents, likely choosing to focus their efforts in towns with greater populations (Interview 2). While Snappcar has a presence in the town, there are usually fewer than a dozen vehicles available on the website.

Towns the size of Umeå can be seen as lacking the critical mass that would bring business model innovation and competition within the community. Nevertheless, Umeå has a Green Parking Payoff scheme that allows property owners and developers to build less parking spaces with developments if they offer access to carsharing, discounted train tickets or access to other sustainable means of transport [91]. While the direct impact of offering carsharing is unknown, a $35 \%$ reduction in $\mathrm{CO}_{2}$ emissions and a $41 \%$ reduction in car use from the residents is expected as a result of the scheme [91]. The city is also building transport hubs that aim to provide multiple services in one convenient location for citizens (Interview 2). Tomtebo Strand is a new development where the city hopes to make it unnecessary to own a car (Workshop). Experiments have also taken place with individual families, facilitated by the city, to go car-free for a designated time and to try alternative mobility options.

\section{Trends in the Urban Mobility Context}

Personal vehicles in use went from 47,617 in 2010 to 55,657 in 2018, a growth of about $16.8 \%$ from 2010 mirroring Stockholm [67]. With the exception of diesel vehicles, all other vehicle types-petrol, electric, etc.- have increased their share, with petrol vehicles almost doubling [67]. While carsharing is seen to play a role within sustainable mobility, biking and public transit are where most of the city's efforts lie and through which the city expects to meet its goal of $65 \%$ of trips taken through these methods [91]; there are no strategic indicators for carsharing as of 2019 (Interview 2). While the town is in full support of carsharing, there are challenges: carsharing can still only succeed in areas where individuals have the economic means to use it, digital solutions can be a barrier to innovative solutions, resistance from citizens unclear about the benefits of reducing car use (Workshop). It was also remarked that, because many people leave town for nature excursions, owning a private vehicle is a part of the culture to enable this (Interview 2). The results of a trial MaaS program further showed that only those conveniently located near a carpool would make use of it, suggesting that housing associations providing carshare services could be a viable solution for increasing usage [92]. 
While bike sharing and small-scale P2P sharing can succeed, large-scale carsharing has not yet been achieved. As the city has focused on providing different sustainable transportation options, mobility as a service is also premature.

\subsection{Cross-Case Analysis}

The four case cities—Stockholm, Gothenburg, Malmö and Umeå-followed a similar pattern with the emergence of cooperative models, followed by an expansion into B2C and P2P models. The P2P models were fairly recent, and the older forms such as cooperative models and B2C models mostly coexisted with little interactions. Due to various regulations preventing cities from showing favoritism to private companies, these organizations have largely evolved without city support in the cases of Stockholm and Malmö. Moreover, despite offering a more flexible and immediate value proposition, free-floating services have struggled with Swedish regulations and having to compete with incumbents, in contrast to the German context [5]. In terms of size and dominance, eventually the car manufacturer-owned company Sunfleet became most dominant in the cities, echoing earlier work on the difficulty of breaking through incumbent business dominance [2,43]. Sunfleet started as a partnership between Volvo and Hertz, two market incumbents in which the initial value creation was selling private vehicles (Volvo) and renting vehicles (Hertz). Within the ecologies of business models perspective, it has been suggested that incumbents can maintain their positions if they adopt carsharing as part of their model [2]. Incumbent firms generally have the resources and infrastructure to pose a threat to competitors, and in this case, Sunfleet benefitted from early entrance into the carsharing market where it established itself as the leading market force, partly thanks to the carsharing infrastructure and support provided by Gothenburg, which allowed it to expand to other markets. Today, Sunfleet is wholly owned by Volvo and is Sweden's largest privately owned carsharing organization with almost 50,000 members and locations all over Sweden [93]. Experimentation with other business models occurred, with organizations like MoveAbout providing the most viable competition for B2C and B2B carsharing, but many did not scale up or ceased to exist.

Regarding the impacts (e.g., congestion and air quality), biking, walking and public transit appear to be the top sustainability priorities in the four cities. Perhaps it is not surprising that carsharing does not have a clear strategic role or priority in the cities, given that public transportation and bicycling remain highly viable options in Sweden. Public transportation and carsharing thus act in a mutualistic fashion, but carsharing has a limited foothold with small numbers of participants and usage per participant. In general, there is a trend in the cities towards more private car ownership, with a dominance of petrol cars but a gradual shift towards more electric vehicles. It is interesting to note that Gothenburg has experienced significantly less growth in new vehicle registration from 2010 compared to Stockholm (a city of similar size and resources). Gothenburg has invested more in carsharing infrastructure and support, yet this positive trajectory may be also related to other mobility options. Finally, different carsharing models may have different impacts: P2P business models leverage existing idle vehicles while $\mathrm{B} 2 \mathrm{C}$ models rely on procuring new fleets during expansion. Despite this, we found that, in the three cities, public procurement has been used to support B2C carsharing (e.g., public procurement of Sunfleet services by Stockholm and Umeå and of Sunfleet and Bilpoolen.nu in Gothenburg).

Because of the potential dominance of private players and the struggle with promoting viable alternatives within a city context, cities might need to consider engaging in carsharing [94]. Cities can take different roles in this, as shown in Table 4. The important parameters in this model relate to three different groups of actors (the city, businesses and volunteer organizations) who initiate issues in the city (compare also [95]). In a process characterized by "governing by provision and authority", the local government starts the initiative. In "governing by partnership and enabling", it is initiated and run collaboratively between the local government and others. In 'governing through volunteers' (e.g., NGOs or citizens), the process lies in the hands of actors other than the local government, and the role of the local government is mainly to support or facilitate these processes. Reasons for local 
governments to engage in volunteer initiatives include the strengthening of the cities' financial and social vitality and the improving quality of the infrastructure in the locations where the initiatives are implemented.

Table 4. Local government's role in carsharing: Developed from Palm et al. [95].

\begin{tabular}{cccc}
\hline $\begin{array}{c}\text { Governing by Provision } \\
\text { and Authority }\end{array}$ & $\begin{array}{c}\text { Governing by Partnership } \\
\text { and Enabling }\end{array}$ & $\begin{array}{c}\text { Governing through } \\
\text { Volunteering }\end{array}$ \\
\hline Local & Local government together \\
with others & Citizens or NGOs \\
& $\begin{array}{c}\text { government/authorities } \\
\text { (e.g., public transport; } \\
\text { public procurement) }\end{array}$ & $\begin{array}{c}\text { (e.g., development of platforms, } \\
\text { such as the MaaS app; Umeå } \\
\text { supporting mobility } \\
\text { experiments with individuals) }\end{array}$ & $\begin{array}{c}\text { (e.g., neighborhood } \\
\text { coops in the 1970s } \\
\text { and 1980s) }\end{array}$ \\
\hline
\end{tabular}

Table 4 is used to analyze how four Swedish cities have contemplated their participation in the sharing economy.

Both Gothenburg and Umeå stressed that, without their initial support for carsharing, no publicly accessible carshare model would have survived. Local governments might take on a partnering role when they want to support an increasing carsharing trend in the city but do not want to lead. They might take a self-governing role when they want to introduce carsharing and to contribute to the establishment of a market. If they want to support initiatives from volunteer organizations, a possible action could be to establish a publicly orchestrated carsharing platform to reduce the search cost for different actors wanting to enter the market. In this set up, the local government may facilitate exchanges between potential customers and carsharing initiatives without interfering in how or by whom the service is offered.

Finally, it is necessary for local policy makers to consider the impact of promoting carsharing on the "environmental sustainability hierarchy" for mobility. Carsharing is not amongst the most environmentally preferable options (biking, walking and public transport), so it would be beneficial for cities to consider what other options are available in their mobility portfolio to contribute to the desired (sustainability) impacts. The cases showed that lenience with car parking was amongst the selling points for users to adopt carsharing, and it has been promoted as part of new building developments. It is important to understand the impact of these initiatives on more environmentally preferable options (e.g., biking) and whether this would not have adverse impacts.

\section{Discussion and Conclusions}

This study investigated how carsharing business models coevolved in four Swedish cities. The contributions are threefold: providing (1) an empirical study on the theoretical concept of the ecologies of business models, (2) an in-depth study on how carsharing coevolved in Swedish cities and in relation to wider sustainability and mobility trends and (3) novel perspectives on the role of local governments in relation to these new carsharing business models.

First, while before, the ecologies of business models perspective had only been theoretically described [2,13], we contribute with an empirical analysis of carsharing in four Swedish cities. The aim was to better understand how carsharing business coevolved and what the impact of such initiatives was in an urban context. While such an analysis does not provide hard quantitative data on the impact of new sharing business models on environmental indicators such as air pollution and $\mathrm{CO}_{2}$ emissions, it does provide a rich understanding of the size of the new industries and business models and the dynamics within the urban context. Anecdotal evidence from the workshop and interviews suggested that the ecologies of business models provided a fruitful perspective for discussion and helps local policy makers compare their options to decide about their future strategies in a sustainability context.

Second, our study gives insight in the impact of carsharing within the urban context. It suggests that carsharing is complementary to existing (private) car usage rather than a replacement. Few 
small players have successfully remained viable in the cities, with the dominance of carsharing tied to an incumbent car manufacturer. Cooperative models, Business-to-Consumer (B2C) models and Peer-to-Peer (P2P) models evolved. However, carsharing is still rather niche in the four Swedish cities. These findings echo work from over a decade ago [16], which concluded that carsharing was niche but worth exploring to counteract negative trends of higher car dependency without substantial increases in public transport. While a dominant player, Sunfleet, emerged in Sweden, this player was not regarded as large in terms of fleet. It is however interesting that this carsharing business is owned by an incumbent car manufacturer, Volvo, showing how incumbents might (sub)consciously keep in place their existing model of car manufacturing but through different customer channels (e.g., sharing next to ownership). We did not find evidence for the "breaking down" of dominant non-sharing business models [43], as would be desirable in the transition to a sharing economy. This was coupled with negative environmental trends of increasing car ownership, with registered vehicles still being on the rise (2006 to 2018) in Sweden [67] and between 2010-2018 in the four cities. We also found that free-floating business models did not "float" so well in Sweden, perhaps because of strict parking regulations and easy accessibility to cycling and public transit, which contrasts the German context, where the free-floating model was introduced, imitated and made scalable by incumbent car manufacturers (Daimler and BMW) [5].

Third, we observed patterns in the key roles of cities in relation to carsharing: enabling carsharing organizations to succeed through procuring sharing services, providing incentives for carsharing organizations through favorable parking fees and reduced parking requirements for new builds and providing information to the public about carsharing. The cities of Malmö and Stockholm also relied on government support (national and/or EU) for the initial start of carsharing, and a mobility as a service project in Stockholm is still reliant on EU funding. Cities have a delicate line to tread between providing explicit support for carsharing, which can come across as private company favoritism, and needing to promote carsharing as a possibly sustainable alternative.

To conclude, despite a 50-year history of carsharing in Sweden, there is still uncertainty about the impacts and carsharing is not yet widespread. This has several implications. First, there is a need to consider the environmental hierarchy of mobility options. Second, it is essential to understand the implications of (not) supporting unsustainable trends (e.g., reliance on cars). Although Cohen and Kietzmann [10] suggested that "further integration between shared mobility operators and cities [is needed] to minimize agency conflicts and increase the sustainability of the business model", we propose the totality of sharing business models in a city context and how these relate to each other, needs to be more fully understood before such integration. To facilitate this, the ecologies of business models concept [2] was found to stimulate interesting debates between decision makers on who they were supporting and what business models they were sustaining through their actions [Workshop]. Finally, carsharing will probably remain a critical part of sustainable mobility efforts by cities, but given that some longer trips cannot easily be replaced with public transportation or cycling, there may be an impetus to owning a private vehicle for convenience. This demonstrates the potential for innovative business models that bridge conventional longer-term car rental and short-term carsharing, resulting in more appealing propositions to entice people to reconsider the need for individual car ownership.

This research contributes to the understanding of the role of carsharing in the sharing economy and sustainability debates by analyzing how carsharing evolved over time in four Swedish cities. Novel insights relate to the ecologies of business models perspective, which supports the understanding of the coevolution of carsharing initiatives over time and the role of the local governments. This study identified mixed involvements by the cities (enabling and incentives), with unclear outcomes for sustainability and little scaling up, except for the rise of one dominant player arising from the incumbent car manufacturing (and rental) industry. Future research may expand on developing the ecologies of business models perspective into a practical "tool" or method to assess new business models within a certain context. Research may also focus on the actual purposes of carsharing and 'what it replaces' through consumer behavior studies to better understand future business strategies 
and local policies. Finally, more insight into the environmental benefits of different types of carsharing initiatives on their own and within a broader city context is needed.

Author Contributions: N.B.: writing - original draft preparation, review and editing; conceptualization; data collection (workshop); methodology; visualization; supervision; project administration and funding acquisition. A.J.: data collection and curation; data analysis; visualization; writing—results section; review; and editing. K.S.: writing-review and editing; and data collection (workshop). J.P.: writing-review and editing; data collection (workshop and interviewing) and funding acquisition. All authors have read and agreed to the published version of the manuscript.

Funding: This research was supported by VINNOVA who funded the "Sharing Business Models" strategic project within the Sharing Cities program, grant number 2018-04646, and the Swedish Energy Agency "Smart symbiosis-collaboration for common resource flows" project, grant number 46016-1.

Acknowledgments: We would like to acknowledge the support of the Lund University IIIEE teams in supporting the cities workshop, in particular, Kes McKormick and Katharina Reindl, and the University of Manchester team, Mike Hodson, Frank Boons, Andy McMeekin and Marc Hudson, for the invaluable discussions that helped shape this research.

Conflicts of Interest: The authors declare no conflict of interest. The funders had no role in the design of the study; in the collection, analyses, or interpretation of data; in the writing of the manuscript; or in the decision to publish the results.

\section{References}

1. Botsman, R.; Rogers, R. What's Mine Is Yours: How Collaborative Consumption is Changing the Way We Live; Collins: London, UK, 2011; Volume 5.

2. Boons, F.; Bocken, N. Towards a sharing economy-Innovating ecologies of business models. Technol. Forecast. Soc. Chang. 2018, 137, 40-52. [CrossRef]

3. Benkler, Y. Sharing Nicely: On Shareable Goods and the Emergence of Sharing as a Modality of Economic Production. Yale Law J. 2004, 114, 273. [CrossRef]

4. Acquier, A.; Carbone, V.; Massé, D. How to Create Value(s) in the Sharing Economy: Business Models, Scalability, and Sustainability. TIM Rev. 2019, 9, 5-24. [CrossRef]

5. Schaltegger, S.; Lüdeke-Freund, F.; Hansen, E.G. Business Models for Sustainability: A Co-Evolutionary Analysis of Sustainable Entrepreneurship, Innovation, and Transformation. Organ. Environ. 2016, 29, 264-289. [CrossRef]

6. Barnes, S.J.; Mattsson, J. Understanding current and future issues in collaborative consumption: A four-stage Delphi study. Technol. Forecast. Soc. Chang. 2016, 104, 200-211. [CrossRef]

7. Kathan, W.; Matzler, K.; Veider, V. The sharing economy: Your business model's friend or foe? Bus. Horiz. 2016, 59, 663-672. [CrossRef]

8. Rachinger, M.; Rauter, R.; Müller, C.; Vorraber, W.; Schirgi, E. Digitalization and its influence on business model innovation. JMTM 2019, 30, 1143-1160. [CrossRef]

9. Münzel, K.; Boon, W.; Frenken, K.; Vaskelainen, T. Carsharing business models in Germany: Characteristics, success and future prospects. Inf. Syst. E-Bus. Manag. 2018, 16, 271-291. [CrossRef]

10. Cohen, B.D.; Kietzmann, J. Ride on! Mobility Business Models for the Sharing Economy. Organ. Environ. 2014, 27, 279-296. [CrossRef]

11. Martin, C.J. The sharing economy: A pathway to sustainability or a nightmarish form of neoliberal capitalism? Ecol. Econ. 2016, 121, 149-159. [CrossRef]

12. Walravens, N.; Ballon, P. Platform business models for smart cities: From control and value to governance and public value. IEEE Commun. Mag. 2013, 51, 72-79. [CrossRef]

13. Bocken, N.; Boons, F.; Baldassarre, B. Sustainable business model experimentation by understanding ecologies of business models. J. Clean. Prod. 2019, 208, 1498-1512. [CrossRef]

14. Aldrich, H. Organisations Evolving; SAGE: Southend Oaks, CA, USA, 1999.

15. Bocken, N.M.P.; Mugge, R.; Bom, C.A.; Lemstra, H.-J. Pay-per-use business models as a driver for sustainable consumption: Evidence from the case of HOMIE. J. Clean. Prod. 2018, 198, 498-510. [CrossRef]

16. Nykvist, B.; Whitmarsh, L. A multi-level analysis of sustainable mobility transitions: Niche development in the UK and Sweden. Technol. Forecast. Soc. Chang. 2008, 75, 1373-1387. [CrossRef] 
17. Richardson, J. The business model: An integrative framework for strategy execution. Strat. Chang. 2008, 17, 133-144. [CrossRef]

18. Teece, D.J. Business Models, Business Strategy and Innovation. Long Range Plan. 2010, 43, 172-194. [CrossRef]

19. Bocken, N.M.P.; Short, S.W. Towards a sufficiency-driven business model: Experiences and opportunities. Environ. Innov. Soc. Trans. 2016, 18, 41-61. [CrossRef]

20. Stubbs, W.; Cocklin, C. Conceptualizing a "Sustainability Business Model”. Organ. Environ. 2008, 21, $103-127$. [CrossRef]

21. Bocken, N.; Short, S.; Rana, P.; Evans, S. A value mapping tool for sustainable business modelling. Corp. Gov. 2013, 13, 482-497. [CrossRef]

22. Kennedy, S.; Bocken, N. Innovating business models for sustainability: An essential practice for responsible managers. In The Research Handbook of Responsible Management. Cheltenham; Laasch, O., Jamali, D., Freeman, E., Suddaby, R., Eds.; Edward Elgar Publishing: Cheltenham, UK, 2019.

23. Curtis, S.K.; Lehner, M. Defining the sharing economy for sustainability. Sustainability 2019, 11, 567. [CrossRef]

24. Heinrichs, H. Sharing economy: A potential new pathway to sustainability. GAIA-Ecol. Perspect. Sci. Soc. 2013, 22, 228-231. [CrossRef]

25. Kamargianni, M.; Matyas, M. The Business Ecosystem of Mobility-as-a-Service; Transportation Research Board: Washington, DC, USA, 2017; Volume 69, pp. 8-12.

26. Frenken, K.; Schor, J. Putting the sharing economy into perspective. Environ. Innov. Soc. Trans. 2017, $23,3-10$. [CrossRef]

27. Lindahl, M.; Sundin, E.; Sakao, T. Environmental and economic benefits of Integrated Product Service Offerings quantified with real business cases. J. Clean. Prod. 2014, 64, 288-296. [CrossRef]

28. Manninen, K.; Koskela, S.; Antikainen, R.; Bocken, N.; Dahlbo, H.; Aminoff, A. Do circular economy business models capture intended environmental value propositions? J. Clean. Prod. 2018, 171, 413-422. [CrossRef]

29. May, S.; Konigsson, M.; Holmstrom, J. Unlocking the sharing economy: Investigating the barriers for the sharing economy in a city context. First Monday 2017, 22. [CrossRef]

30. Davidson, N.M.; Infranca, J.J. The sharing economy as an urban phenomenon. Yale Law Policy Rev. 2015, $34,215$.

31. Kramers, A.; Ringenson, T.; Sopjani, L.; Arnfalk, P. AaaS and MaaS for Reduced Environmental and Climate Impact of Transport. In Proceedings of the 5th International Conference on Information and Communication Technology for Sustainability (ICT4S), Toronto, ON, Canada, 14-18 May 2018; pp. 1-16.

32. Palm, J.; Smedby, N.; McCormick, K. The role of local governments in governing sustainable consumption and sharing cities. In A Research Agenda for Sustainable Consumption Governance; Edward Elgar Publishing: Cheltenham, UK, 2019.

33. Valsecchi Ribeiro de Souza, J.; Marotti de Mello, A.; Marx, R. When Is an Innovative Urban Mobility Business Model Sustainable? A Literature Review and Analysis. Sustainability 2019, 11, 1761. [CrossRef]

34. Kent, J.L.; Dowling, R. Puncturing automobility? Carsharing practices. J. Transp. Geogr. 2013, 32, 86-92. [CrossRef]

35. Li, Y.; Voege, T. Mobility as a Service (MaaS): Challenges of Implementation and Policy Required. JTTs 2017, 7, 95-106. [CrossRef]

36. Bocken, N.M.P.; Short, S.W.; Rana, P.; Evans, S. A literature and practice review to develop sustainable business model archetypes. J. Clean. Prod. 2014, 65, 42-56. [CrossRef]

37. Jittrapirom, P.; Caiati, V.; Feneri, A.-M.; Ebrahimigharehbaghi, S.; González, M.J.A.; Narayan, J. Mobility as a Service: A Critical Review of Definitions, Assessments of Schemes, and Key Challenges. UP 2017, 2, 13. [CrossRef]

38. Goodall, W.; Fishman, T.; Bornstein, J.; Bonthron, B. The Rise of Mobility as a Service: Reshaping how Urbanites get Around; Special Section: Future of Mobility, Deloitte Review; Deloitte: London, UK, 2017.

39. Pangbourne, K.; Stead, D.; Mladenović, M.; Milakis, D. The Case of Mobility as a Service: A Critical Reflection on Challenges for Urban Transport and Mobility Governance. In Governance of the Smart Mobility Transition; Marsden, G., Reardon, L., Eds.; Emerald Publishing Limited: Bingley, UK, 2018; pp. 33-48. ISBN 978-1-78754-320-1.

40. SEA (Swedish Energy Agency) Mobility as a Service-Experiences from the Nordic Countries; SEA: Eskilstuna, Sweden, 2019. 
41. Giesecke, R.; Surakka, T.; Hakonen, M. Conceptualising Mobility as a Service. In Proceedings of the 2016 Eleventh International Conference on Ecological Vehicles and Renewable Energies (EVER) IEEE, Monte Carlo, Monaco, 6-8 April 2016; pp. 1-11.

42. Mair, J.; Reischauer, G. Capturing the dynamics of the sharing economy: Institutional research on the plural forms and practices of sharing economy organizations. Technol. Forecast. Soc. Chang. 2017, 125, 11-20. [CrossRef]

43. Sarasini, S.; Linder, M. Integrating a business model perspective into transition theory: The example of new mobility services. Environ. Innov. Soc. Trans. 2018, 27, 16-31. [CrossRef]

44. Palm, J.; Backman, F. Public procurement of electric vehicles as a way to support a market: Examples from Sweden. Int. J. Electr. Hybrid Veh. 2017, 9, 253-268. [CrossRef]

45. Statistics Sweden Population in the State, Counties and Municipalities 31 March 2019 and Population Changes 1 January-31 March 2019. 2019. Available online: https://www.scb.se/en/finding-statistics/statisticsby-subject-area/population/population-composition/population-statistics/ (accessed on 11 February 2020).

46. Sharing Cities Sweden Sharing Cities Sweden. Available online: https://www.sharingcities.se/ (accessed on 11 February 2020).

47. World Population Review Population of Cities in Sweden. 2019. Available online: http:// worldpopulationreview.com/countries/sweden-population/cities/ (accessed on 9 December 2019).

48. Strid, M. Sweden-getting mobilised. World Transp. Policy Pract. 2000, 5, 89-95.

49. Akyelken, N.; Givoni, M.; Salo, M.; Plepys, A.; Judl, J.; Anderton, K.; Koskela, S. The importance of institutions and policy settings for car sharing-Evidence from the UK, Israel, Sweden and Finland. Eur. J. Transp. Infrastruct. Res. 2018, 18, 340-359.

50. Shaheen, S.A.; Cohen, A.P. Growth in Worldwide Carsharing: An International Comparison. Transp. Res. Rec. 2007, 1992, 81-89. [CrossRef]

51. SAMBIL Bilpool SAMBIL. Available online: http://www.sambil.se/ (accessed on 11 February 2020).

52. SCB. Registered Passenger Cars in Use, 1923-2018; SCB, 2019. SCB. Available online: https://www.scb.se/en/finding-statistics/statistics-by-subject-area/transport-and-communications/ road-traffic/registered-vehicles/pong/tables-and-graphs/registered-passenger-cars-in-use/ (accessed on 11 February 2020).

53. Loose, W. The State of European Car-Sharing: Final Report D 2.4 Work Package 2; Intelligent Energy Europe; Bundesverband Carsharing: Berlin, Germany, 2010.

54. Blotenburg, S. Car sharing platform SnappCar acquires Swedish competitor. Startup Juncture, 2015. Available online: https://startupjuncture.com/2015/10/20/car-sharing-platform-snappcar-acquires-swedish-competitor/ (accessed on 11 February 2020).

55. Go More about. Available online: https://gomore.se/about (accessed on 11 February 2020).

56. Skatteverket. Skatteverket Delningsekonomi: Kartläggning och analys av delningsekonomins påverkan på skattesystemet; Skatteverket: Solna Municipality, Sweden, 2016; pp. 1-61.

57. Sveriges Radio. Simon Rissvik. Sweden. 31 January 2018. Available online: https://sverigesradio.se/sida/ artikel.aspx?programid=104\&artikel=6873352 (accessed on 28 November 2019).

58. Sunfleet Bilpool i Göteborg|Här kan du hyra våra bilar. Available online: https://www.sunfleet.com/bilpooler/ goteborg/ (accessed on 11 February 2020).

59. Bilpoolen.nu Bilpoolen.nu. Available online: http://www.bilpoolen.nu/ (accessed on 2 June 2019).

60. Gröna Bilister Att dela bil. Available online: http://www.gronabilister.se/lankar/att-dela-bil-bilpooler (accessed on 27 November 2019).

61. Move about om move about. Available online: http://www.moveabout.se/About/Om-Move-About (accessed on 2 June 2019).

62. Jagelid, M. Move About and Miveo Join Forces. 2017. Available online: https://www.miveo.se/2017/07/11/moveabout-and-miveo-joins-forces/ (accessed on 11 February 2020).

63. City of Gothenburg. City of Gothenburg Goals and Focus to Promote Carsharing Development in Gothenburg; City of Gothenburg: Gothenburg, Nebrask, 2012.

64. Göteborgs Stad. Parkeringspolicy för göteborgs stad: Antagen av Kommunfullmäktige 2009-10-08; Göteborgs Stad: Stockholm, Sweden, 2009.

65. City of Gothenburg Gothenburg 2035: Transport Strategy for a Close-Knit City; Urban Transport Committee: Gothenburg, Sweden, 2014. 
66. Göteborgs Stad. Miljömålsuppföljning (Environmental Objectives Monitoring); Göteborgs Stad: Stockholm, Sweden, 2017.

67. Trafik Analys. Trafik Analysys Fordon på väg, 12 March 2019. Available online: https://www.trafa.se/vagtrafik/ fordon/ (accessed on 11 February 2020).

68. Sunfleet Bilpool i Stockholm|Här kan du hyra våra bilar. Available online: https://www.sunfleet.com/ bilpooler/stockholm/ (accessed on 11 February 2020).

69. Lindroth, J. Stockholms parkeringselände sätter P-Car2go lämnar Sverige. VA, 2016. Available online: https://www.va.se/nyheter/2016/09/30/car2go-lamnar-stockholm/https://www.va.se/nyheter/2016/ 09/30/car2go-lamnar-stockholm/ (accessed on 11 February 2020).

70. Habibi, S.; Sprei, F.; Englund, C.; Pettersson, S.; Voronov, A.; Wedlin, J.; Engdahl, H. Comparison of Free-Floating Car Sharing Services in Cities; ECEEE: Stockholm, Sweden, 2017.

71. Manthey, N. Sumitomo Starts Electric Car Sharing in Stockholm; Electrive. Com: Berlin, Germany, 2018.

72. Karlsson, J. BMW:s bildelningstjänst lägger ner i Sverige. Digital, 2018. Available online: https://digital.di.se/artikel/bmws-bildelningstjanst-lagger-ner-i-sverigehttps://digital.di.se/artikel/ bmws-bildelningstjanst-lagger-ner-i-sverige (accessed on 11 February 2020).

73. O'Dolan, C. Car Sharing and Car Pooling. Stockholm. Sweden. Available online: https://www.eltis.org/ discover/case-studies/car-sharing-and-car-pooling-stockholm-sweden (accessed on 11 February 2020).

74. Sunnerstedt, E. Joint Procurement of EVs and PHEVs in Sweden: Clean Fleets Case Study; Clean Fleets: Sacramento, CA, USA, 2013.

75. Stockholm Stad. Mobilitetsindex-värdering av hålbart resande i Södra Värtan; Stockholm Stad: Stockholm, Sweden, 2016.

76. Stockholm Stad. Stockholm Action Plan for Climate and Energy 2010-2020; Stockholm Stad: Stockholm, Sweden, 2010.

77. Firth, D. Urban Mobility Plan; Stockholms Stad: Stockholm, Sweden, 2012.

78. Stockholm Stad. Byt bilen mot ett Reseabonnemang. Available online: https://www.stockholm.se/Fristaendewebbplatser/Fackforvaltningssajter/Miljoforvaltningen/Miljobilar/Nyheter-och-press/Nyheter-och-press/ Nyheter/Byt-bilen-mot-ett-reseabonnemang/ (accessed on 27 November 2019).

79. Mortkowitz, S. MaaS Set to Get Rolling in Stockholm. Automative, 7 February 2019. Available online: https://www.tu-auto.com/maas-set-to-get-rolling-in-stockholm/ (accessed on 11 February 2020).

80. Stockholms läns landsting. Resvanor i Stockholms län 2015; Trafikförvaltningen: Stockholm, Sweden, 2016; pp. 1-81.

81. Stockholms Stad. Invånare Som Kör Bil Från Bilpool; Stockholms Stad: Stockholm, Sweden, 2019.

82. CIVITAS. Towards a Sustainable Transport System in Malmö, Norwich, Potenza, Suceava and Tallinn; CIVITAS: Malmo, Sweden, 2010.

83. CIVITAS. Fifth Carpool Opens in Malmö. Available online: https://civitas.eu/content/fifth-carpool-opensmalm\%C3\%B6 (accessed on 11 February 2020).

84. Sunfleet Bilpool i Malmö|Här kan du hyra våra bilar. Available online: https://www.sunfleet.com/bilpooler/ malmo/ (accessed on 11 February 2020).

85. Folett, N.; Henderson, J. Low Car(bon) Communities: Inspiring Car-Free and Car-Lite Urban Futures, 1st ed.; Routledge: Oxon, UK; New York, NY, USA, 2016; ISBN 978-1-138-82586-4.

86. Malmö Stad. Comprehensive Plan for Malmö: Summary in English. Adopted by Malmö City Council on May 22nd 2014; Malmö Stad: Malmö, Sweden, 2014.

87. Malmö Stad. Sustainable Urban Mobilty Plan: Creating a More Accessible Malmo; Malmö Stad: Malmö, Sweden, 2016.

88. Malmö stad. Resvanor och Trafikmätningar. Available online: http://miljobarometern.malmo.se/trafik/ resvanor-och-trafikmatningar/ (accessed on 11 February 2020).

89. Björkstadens Miljöbilpool Om oss. Available online: http://www.miljobilpool.se/om/ (accessed on 11 February 2020).

90. Ålidhems Bilpool Fakta om Ålidhems Bilpool. Available online: http://trafikkonsult.se/alidhem.html (accessed on 11 February 2020).

91. Umeå Kommun. EGCA 2018, Umeå, Sweden; Umeå Kommun: Umeå, Sweden, 2018.

92. Umeå Kommun. Tre månader Utan Bil; Umeå Kommun: Umeå, Sweden, 2018. 
93. Isakkson, A.B. Så hittar du rätt bilpool. Allt om Billar., 9 September 2016. Available online: https: //www.expressen.se/motor/guider-2/sa-hittar-du-ratt-bilpool/ (accessed on 11 February 2020).

94. Bulkeley, H.; Kern, K. Local Government and the Governing of Climate Change in Germany and the UK. Urban Stud. 2006, 43, 2237-2259. [CrossRef]

95. Palm, J.; Södergren, K.; Bocken, N. The role of cities in the sharing economy: Exploring modes of governance in urban sharing practices. Energies 2019, 12, 4737. [CrossRef]

(C) 2020 by the authors. Licensee MDPI, Basel, Switzerland. This article is an open access article distributed under the terms and conditions of the Creative Commons Attribution (CC BY) license (http://creativecommons.org/licenses/by/4.0/). 